\title{
On the Pending Robot Revolution and the Utopia of Human Agency
}

\author{
By Daniel Bodén
}

\begin{abstract}
A hallmark of modernist thought is the belief in science and technology as a socially revolutionary force. Consequently, new technologies have often been sequenced by pictures of another world to be. The birth of electronic data processing (EDP) was no exception. Provoking both hopes and anxieties, EDP and its subsequent process of automation has, ever since the launch of the first electronic data processing machines in the early 1950 's, been a cornerstone for countless extravagant visions of the future, such as the thought of an ever so impending "Robot Revolution". This article builds from the basic assumption that visions of the future draw on notions of what at a given time is considered socially and politically desirable, unwanted or at all possible. It thus argues that the robot revolution could be studied as a form of reified anticipation through which possible social trajectories are made symbolically comprehensible. Focusing on the automation debate of the Swedish 1950's, I argue that the robot revolution serves as a symbolic articulation of the social experiences of Swedish welfare society, and that it carries both ideological and utopian dimensions worth examining.
\end{abstract}

Keywords: robots, modernity, automation, capitalism, ideology, utopia

Bodén, Daniel: "On the Pending Robot Revolution and the Utopia of Human Agency", Culture Unbound, Volume 10, issue 2, 2018: 208-225. Published by Linköping University Electronic Press: $\underline{\text { http://www.cultureunbound.ep.liu.se }}$ 
No theory applies to that which lies beyond the realm of the immaterial. That which has, as yet, no material existence cannot crystallize materially. The spirit which leads into the realm of tomorrow can only be recognized by the sense (guided by the artist's talent). (Kandinsky 1946: 23)

The future is always a central dimension of political discourse. Whether the motivation driving reforms, investments or policy is to instigate change, or to preserve status quo, it has to draw from a notion of what the world could or should be like. This article builds from the basic assumption that visions of the future draw on notions of what at a given time is considered socially and politically desirable, unwanted or at all possible. It argues that the Future could be studied as a form of "anticipatory knowledge" (cf. Godhe's article in this issue) and suggests that the different contributions to the discourse on the Future could be studied as a way through which real social experiences and anticipations are processed and made symbolically comprehensible. In that sense, any depiction of the future is at the same time a reified document of its contemporary circumstances. As such, I argue that depictions on the future carry both ideological and utopian dimensions. "Ideological" in the sense of imposing values and ideas that confirm, legitimate and naturalise dominant social value systems, and "utopian" in the sense that they imply an opportunity to transcend what is explicitly articulated and to imagine a potential "otherwise" (cf. Eagleton 1991: 1f, 106).

Delimiting the study to the Swedish 1950s, this article focuses on one particular discourse on the future, namely that of a pending "Robot Revolution", often reoccurring in the Swedish press at the time. The analysis centres itself around how the vision of a pending Robot Revolution appeared in the contemporary press and in political debate. By studying how the discourse on the Robot Revolution was articulated, and analysing its sub-textual assumptions, the article attempts to discover its implied utopian potential.

\section{Sketches of the social}

It could be argued that it is outside the scope of any photograph to picture anything that has not occurred. Since photography places its focal point on events, "out there" in the world and documents them, a photograph is inevitably bound to represent past events, or at best a present in its unfolding. For this simple reason, the photograph rarely transcends the depicted events "for the sake of something else", as the famous Roland Barthes once commented (Barthes 1981: 4). Sketching, on the other hand, provides the opportunity of expressing fictive events gathered from the mind of the creator (Berger 2007). As it relies on the coordina- 
tion between the mind, the eye and the hand holding the pen, it draws from, and expresses what the creator knows, feels, remembers or can imagine. And since knowledge is inescapably social, sketches could be studied as "social acts" (cf. Jameson 2002).

While browsing through a batch of digitised newspapers at the National Library of Sweden in Stockholm, I recently came across a series of articles that caught my curiosity. Stretching over a period of ten years (1950-1960), the major Swedish newspapers spent considerable amounts of ink debating and reporting on the development of electronic processing machines and the subsequent process of "automation" that they made possible within the productive sectors. The different pieces of journalism ranged from interviews with experts and engineers to union representatives and politicians, to reports from different industries and informative explanations of the functions of the new machines. But rather than accompanying texts with photographs, which indeed was a common feature in the journalism of the time, many of the articles were accompanied by sketches and drawings. The drawings were often elaborate, detailed, bizarre and fantastic, and instead of documenting or reporting the present, they often seemed to depict what different experts and visionaries thought were about to happen in a near future. Altogether the pictures often came down to two common denominators: the "Robot", and the inevitability of its ascendancy - the Robot Revolution.

In The $20^{\text {th }}$ of September 1951, the Swedish independent conservative daily newspaper, Svenska Dagbladet published a letter to the paper with the title "Machine dictatorship". Accompanied by a rather dramatic sketch (see figure 1, next page), the letter voiced one reader's concerns regarding an article, published earlier the same week. The article in mention had reported on the development of electronic data processing, a new and significant technology through which machines could be taught to think and make their own decisions and had further suggested that it was only a matter of time until human work and decision making in the industry altogether could be replaced by intelligent machines (Svenska Dagbladet 19.09.1951). In the sketch, readers were faced with the portrayal of a gigantic robot causing havoc in the downtown of some city. With its eyes locked and fixated in front of it, the creature stared blankly out across the lives, buildings and city blocks it was about to mangle over and alter beyond recognition. Indifferent to the trace of destruction it left behind, the juggernaut stretched its mechanical arms out in front of it as if reaching for a world ahead, unknown to the observer, who was left oblivious to the trajectory of the mechanic marauder. Humanity was left standing at a distance, helplessly marvelled while observing its onslaught (Svenska Dagbladet 20.09.1951).

Other sketches (in fact most other images) struck a slightly more optimistic chord. In a sketch illustrating an article in the liberal evening paper Expressen 


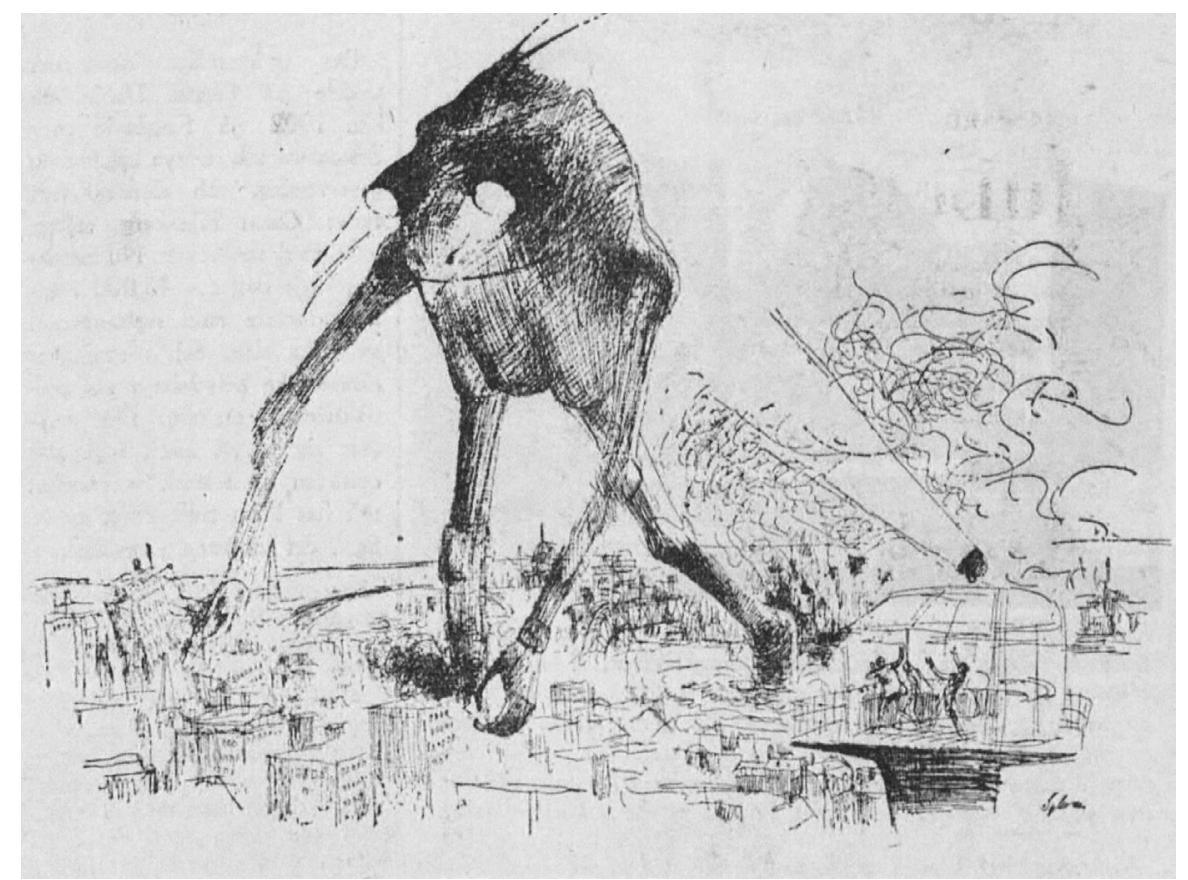

Figure 1. Under the title "Machine dictatorship", the artist depicted a gigantic robot causing havoc. Artist: unknown (Svenska Dagbladet 20.09.1951, National Library of Sweden)

the new and "intelligent" machines were described as benevolent helpers to the inconveniences of humanity's previous predicaments (see figure 2, next page). In the sketch illustrating the article, readers were faced with the image of a machine, rewarded with mathematical abilities extending well beyond those of any ordinary human. In the drawing, readers found a big, shiny robot with all its bells and whistles, positioned in a contemplative pose. While a man in his white robe, equipped with a primitive pen and abacus sits in the margin, scratching his head in bewilderment, the machine seemingly produces yet another rational solution (Expressen 14.08.1955).

In contrast to each other the sketches drew a rather contradictory horizon of expectation. In the different depictions, the new machines would either usher in a surplus society and liberate humanity from the drudgery of labour, or a world dictated by machines, where humanity itself had become superfluous. At the same time, however, the sketches were in themselves highly ambiguous. Looking at their composition they both drew from the tension between an active agent and its passive spectators, between the powerful and the frail, between creation and destruction, between what was known and a future unknown, and between the seemingly advanced and the primitive - positions that were in both images played out through the juxtaposition of humans and machines. 


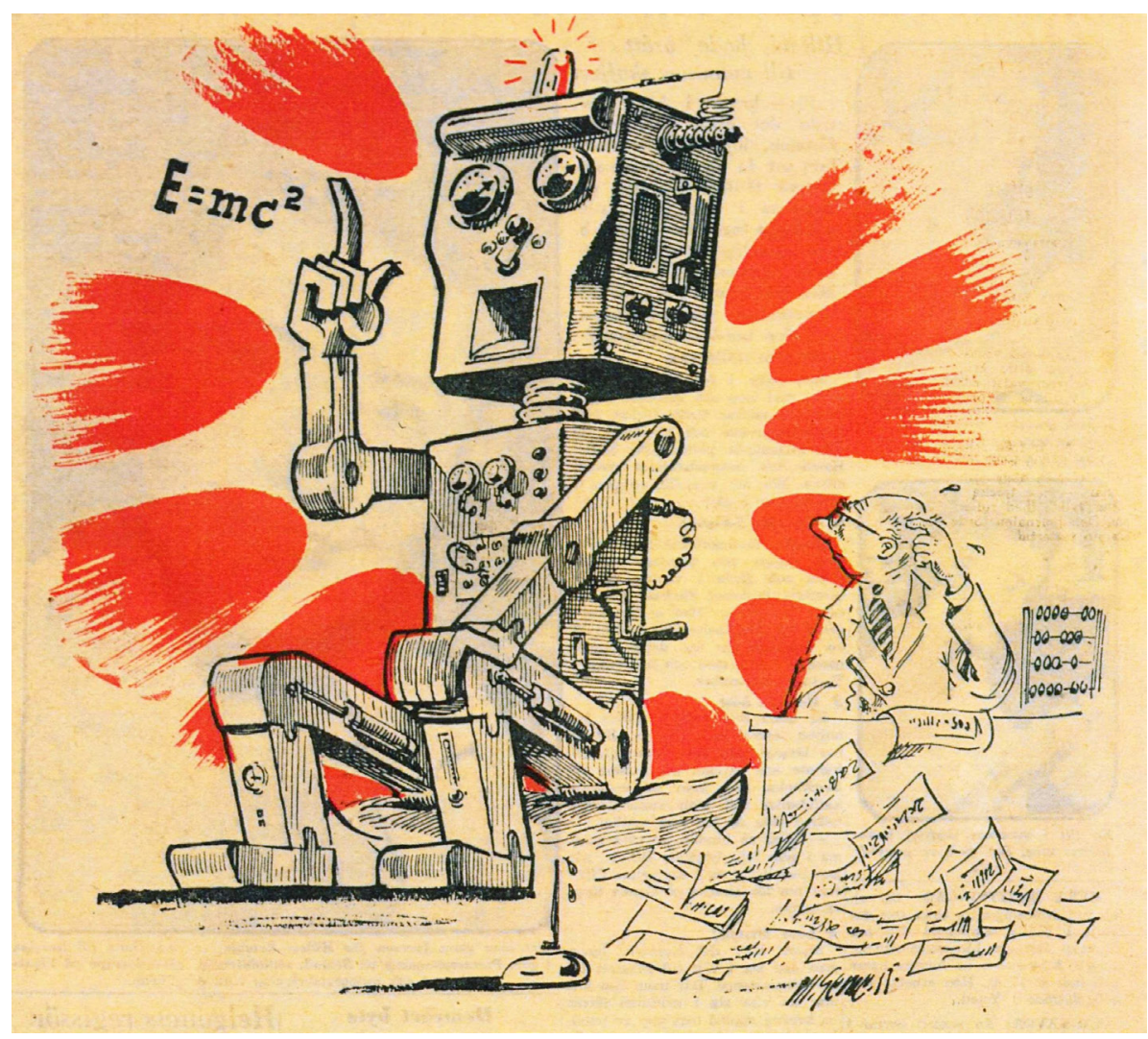

Figure 2. A thinking robot, operating independently to help with calculations. Artist: unknown, (Expressen, 14.08.1955, National Library of Sweden)

In his famous recitation of Marx, "All that is solid melts into air", the philosopher Marshall Berman once argued that ambiguity was a distinctive feature of the social experience of "modernity". According to Berman, to experience one's world and oneself to be in a continuous and contradictive process of disintegration and renewal was indeed to be "modern". But this experience of a world in constant flux, however, did not arise from a vacuum. It was a consequence of the imperative to constantly revolutionise the forces of production embedded in capitalism (Berman 1982: 15, cf. Marx 1990).

Described as such, others have argued that the open-endedness of modern life comes imbued with undefined hopes and anxieties, uncertainties regarding the future through which people must learn to navigate. According to the German philosopher Ernst Bloch for instance, modern experience is therefore pervaded by continuous efforts to conceptualise, interpret and anticipate the trajectory of change, or as he himself called it: the "not-yet". In such a state of being, Bloch argued that art had an important function to fill. According to Bloch, works of art 
offered distinct shapes and forms through which the perceived flux could be imagined and made comprehensible (Bloch 1995: 110). In that sense, art and fiction could be interpreted as therapeutic measures for people to come to terms with the possible and often contradictory anticipations of the world ahead.

In his classical article The Structural Analysis of Myth, the French anthropologist Claude Levi-Strauss argued that people process and resolve the perceived complexity of social life by staging and dramatizing contradictory experiences symbolically (Levi-Strauss 1955). By depicting - or reifying - that which otherwise lacks contours, vague hopes, anxieties and anticipations can be transformed into well-defined and manageable emotions and expectations through which people find purpose and direction. Since art and fiction symbolically reflect social experiences and values, the American literary critic Fredric Jameson suggests that they should be studied as documents of a certain point in social history (Jameson 2002: 276f).

From this rather theoretical note, I will now leave the aesthetic representations of the future and move on to a more in-depth analysis of what was being held as socially "true" about the future at the time. In the following pages I therefore turn to the contemporary press and the archives of political organisations and social movements such as the Swedish Trade Union Confederation (LO), the Swedish Employers Association (SAF), and the Workers' Educational Association $(\mathrm{ABF})$, to analyse the media coverage and political debate on automation. The different articles and documents here serve as an empirical totality through which the Robot Revolution as it appeared in the images above, can be made comprehensible and approached hermeneutically. I will begin with a discussion regarding the factual material and technological conditions upon which artistic representations of a Robot Revolution became at all possible. I will then go on to analyse the socio-political and ideological formations facilitating such visions during the 1950s.

\section{Automation}

1946 has been pointed out as the year when the first electronic "computer" was invented. Originally designed to calculate artillery firing tables for the United States' Army's Ballistic Research Laboratory, the machine (ENIAC) would come to revolutionise humanity's ability to solve numerical problems worldwide. After a few years, in 1950 the first Swedish prototype BARK was built and soon followed by the more advanced BESK, which for a short while was considered the worlds fastest electronic computer (De Geer 1992a). The new computing machines proved incredibly efficient in computing prognoses and performing administrative functions, whereby new prospects for organising industry emerged. 
Many journalistic pieces of the 1950s concentrated on how electronic data processing machines and new advancements in microelectronics allowed machines to communicate and to synchronise with each other. As technology advanced and the computing machines could be integrated in a circuit together with other machines, the idea was that machine systems now could be made highly autonomous and given full responsibility for production. Routine tasks and decisions that previously dominated production, distribution and administration could be transferred onto machines (Ny teknik - nya perspektiv 1954: 36ff). In an already highly industrialised Sweden, "automation" therefore inescapably became a commonplace concept that people had to relate to, one way or another. "Machines are operated by buttons. And the buttons are operated by - machines. This is automation. The fully automated factory", one header in the liberal evening paper Expressen commented (Expressen 21.02.1955). ${ }^{1}$

In a close future, stores, warehouses and factories were expected to be depopulated as production, consumption and transport could be run by intelligent machines. "The experts not only believe in the fully automated factory but also on the fully automated warehouse, department store and office", one could read (Expressen 14.08.1955).

As argued by the historian Tessa Morris-Suzuki, such thoughts followed a clear pattern. Automation has often been described as a linear process by which machines grow larger and larger, and workers fewer and fewer, until all that remains of the factory is one single "megamachine" (Morris-Suzuki 1984). However, the idea of an autonomous factory was by no means new. In a pamphlet published by the Educational bureau for Swedish industry, aimed to enlighten corporate leaders and students in technology about automation, assistant manager of The Royal Swedish Academy of Engineering Sciences, Gregory Ljungberg wrote that automation was a "line of development, containing both old and new" (Automationen: fakta och följder 1956: 7). He further explained that:

As automation replaces human labour power it continues a process that has been going on for hundreds of years, and that was especially visible during the industrial revolution by the end of the $18^{\text {th }}$ Century. At that time a number of mechanical and partially automatic apparatuses and machines appeared [...] Development has since then gone further, and all the more forms of work has become susceptible to automation. (Automationen: fakta och följder 1956: 8f)

Regardless of whether automation really was new or not, advancements in electronic data processing and the incorporation of computing machines into electronically controlled production systems certainly constituted a new palpable oppor- 
tunity to finally realise the vision of total automation. In fact, the first signs of its pending realisation were already visible.

In a report from the Swedish Co-operative Union's new coffee factory in Gothenburg, readers were given insight into the new conditions that characterized the production of their particular brand of coffee. In the coffee factory, management had invested in new machines by which the roasting process had been largely automated. By means of electronic data processing the cooperatively-owned company had been able to replace large parts of manual work with automated machine processes. The new roasting factory was thereby one of the first consistently automated facilities of its kind throughout Sweden. To the journalist behind the article, the new factory appeared as a precursor of a future soon to come. With the help of machines, it was argued, the product would in the future become cheaper and the quality more predictable, and work less demanding.

Throughout the facility the rustling of pipes, the independent releasing of pneumatic locks, slamming slots, whistling valves and the quiet whizzing of fans bore witness of the ongoing production process as the coffee moved through stainless drums from station to station, making the lights on the dashboard blink. In front of the dashboard stood the operator, with notebook and tables ready in hand. Dressed in his characteristic white robe he walked the halls alone, controlling the bells and whistles of the company's new self-regulating coffee roasting machine system. After switching on the main power in the morning and starting the process, he usually took a few routine rounds around the roster to make sure that all numbers and levels were right so that the machine could do its job properly. The older, "primitive" know-how that used to characterise the roasting process had been transferred to the machines. Taste, smell and feel had been standardized and translated into programme code by means of electronic data processing. Scientifically designed tariffs and mathematical calculations would guarantee the best results with accurate and consistent quality. The task of the operator was to check that the coffee's passing through the cleaner, the coffee silos and the reservoir, via the roasting machine and the refrigerator to the scale and the cleaning bowl went smoothly. Panels with flashing indicator lights, controls and meters announced the progress and signalled whether he needed to intervene in the process (Expressen 21.02.1955). The operator's job was now to interpret and follow the signals of machines. The machines were now in charge.

\section{And "progress" for all}

New inventions have often fostered imaginative visions of the future and allowed people to ponder upon the world to be. In this sense, electronic data processing was no exception. Under titles such as "Technology and the future", journalists, ex- 
perts and politicians took the technological advancements of the day as a point of departure to develop their thoughts on the future (Svenska Dagbladet 19.09.1955). Piece by piece, a progressivist vision assembled through the numerous articles, reportages and essays. This future was depicted rather positively. New machines would bring the world into an era where the standard of living would rise dramatically and many of the problems of the day would become history.

Such a vision not only reflected the attitude among the liberal and conservative press, but the attitude of the Swedish labour movement as well. The Swedish labour movement had early on adopted an approach that heeded to a consensus regarding the "benefits" of new technology:

One of the most important tasks of the labour movement is to improve the material standard of their members. The Swedish labour movement has long been aware that a prerequisite for the success of these endeavours is a progressive increase in productivity. Continuous introduction of new technological methods and organisational solutions is an inescapable element in such a development (Landsorganisationen i Sverige 1966: 21).

The 1950s, have often been described as the golden era of Swedish welfare society. The Swedish post-war economy was booming and its ideological superstructure "the peoples home" was at a peak. ${ }^{2}$ This was partially due to a particular model of solidary wage policy brought forth by the Swedish Trade Union Confederation (LO) that created incentives for successful companies to raise their productivity levels by investing in constant capital such as new, more efficient machines. Allowing the more competitive companies to set the standard wage was expected to push companies to invest in new technologies in the struggle for competitive advantage. The main thrust of the model was not only that companies and shareholders were expected to benefit as capitalists reinvested surplus value into new machines. The increase in productivity that was expected to follow investments in new machines was considered a precondition for both prosperity and tax-based universal welfare, which would also benefit those workers that got laid off following rationalisations in terms of unemployment funds and opportunities for re-skilling. The primary objectives of the LO thus boiled down to productivity, income equalisation and the redistribution of wealth (Landsorganisationen i Sverige 1966: 22). Altogether the relation between capital and the (predominantly social democratic) labour movement was in this fashion centrally governed by consensus on the necessity of continuous workplace rationalisations and investment in new technology for the sake of socio-economic development (Isacson 2012: 158; De Geer 1992b: 89f; Beckman 1990: 32). ${ }^{3}$ 
As shown by the example on the Co-operative Union's new coffee factory, Swedish industry had by this time already begun to reap some of the benefits of automation. Governed by electronic data processing, the new and integrated machine systems had demonstrated radical increases in productivity and reduced production costs. Ongoing investments in such new technologies were in this way accepted on the basis of the revenues that they would ultimately yield, and electronic data processing became the lead star in a pending "technological revolution" ushering in far reaching social change (Expressen 22.02.1956). As the intelligent machines seized control of the production process, it was said that society would reach new levels of prosperity. In the independently social democratic evening paper Aftonbladet readers were presented with the merits of automation: "In 1980 - after just over twenty years - our standard of living will be doubled, shortly after the year 2000 it will be fourfold and around 2025 eightfold, many engineers say, economists confirm, and politicians proclaim" (Aftonbladet 09.07.1957).

The new systems of machine production sparked ideas of the prospect of a radically different life. On an everyday level, the new technologies evoked serious hopes for a future in which people were liberated from undesirable and time-consuming work, by allegedly taking over grievous calculations, planning of the labour process, advanced prognostications, heavy lifting and dangerous transportations (Dagens Nyheter 02.01.1955). Work would no longer be exhausting and degrading but stimulating and serve to the betterment of human values. Working hours would be reduced to half and the opportunities for recreation and self-fulfilment would improve. Automation was expected to provide higher incomes, give people more leisure time and produce more commodities to lower prices, thus providing people more money and time for consumption of commodities and the chance to enjoy a higher material standard of living (Expressen 14.08.1955; Expressen 23.08.1955).

\section{The fetish of automation}

In this fashion, automation was described as a catalyst, propelling the world into a new gilded age. And as the train towards the future was about to depart, it seemed best not to be the last passenger to get onboard. One person, already onboard was the social democratic Prime Minister Tage Erlander. Following one conference on technology he proclaimed his "strong sense of the necessity of adapting to an existence in the era of automation and nuclear energy. Incidentally, we have no choice" (Aftonbladet 17.11.1955). A few months later Sven A. Hansson, a journalist at the liberal daily paper Stockholms-Tidningen rather dramatically summarized the sentiment: "Accept or die" (Stockholms-Tidningen 05.05.1956).

In this way, the jargon among politicians, scientists and journalists alike was 
noticeably deterministic. Altogether, the different visions of the future reflected a social reality determined by a "technological imperative", that is: the principle that, that which seems technically possible, ought, must, and inevitably will happen. Such an outlook accurately echoed the dominant ideology of its time, i.e. that as capitalists and labour movement alike treated continuous rationalisations as a necessary measure for socio-economic development, automation appeared inevitable and natural (cf. Carlsson 1999). Under such an ideological premise, the discourse on automation decidedly assumed some fetishist tendencies: It started treating technological development and automation as an estranged force on its own rather than as the result of social practice.

Technological fetishism would express itself both in direct relation to machines, as well as in relation to technological development as such, as an abstract and structural phenomenon. "Now the human brain will be replaced by machines", Expressen announced. In the article the author clarified that "the difference between automation and mechanisation is that the latter aimed at replacing muscles with machines, while the former teaches the machines to think" (Expressen 22.06.1955). In articles and debates, human features were projected onto the machines using the human body as a point of reference (Ny teknik - nya perspektiv. 1954b: 256ff). Electronic machine systems were compared and evaluated in the image of the human body. As earlier mechanisations of the industry had replaced arms, legs and muscle power, automation was now described as the further replacement of human sensory and intellectual properties.

Photocells imitated eyes, helping machines to "see". Scales, thermometers and sensors made them "feel" while programmes allowed them to "think". At the same time electronic circuits were interpreted as a nervous system connecting the organs, limbs and members of a living organism: "Feed-back is an invention made of life itself. In living creatures, there are a lot of feed-back loops': the nervous system gives a muscle the order to act, other nerves report how the muscle works, and the interaction continues until the desired outcome is achieved", the Swedish science reporter Lennart Edberg explained (Expressen 22.06.1955).

Following the ability of the electronic data processing machines to iterate their decision-making processes with the help of feedback loops, the new machine systems were (at least rhetorically) given an agency on their own. Sensory organs and the ability to calculate incoming data seemed to allow the machines to draw conclusions and adapt to an external reality in order to achieve set goals. Governed by an automatic command centre the machine system was therefore increasingly seen as something that resembled "a mechanical monster whose body fills whole factories, and whose demonic power [...] bursts forth in the fast and feverish whirl of its countless working organs", as was written in a famous passage in $\mathrm{Ca}$ pital (1867) (Marx 1977: 503). The integrated electronic circuit of machine parts 
assumed the appearance of an independent artificial worker - a "robot", powered by a spirit independent of man.

The robot has a memory - magnetised drums and steel bands, punchcards, electronic tubes, pressure sensitive crystals, sound sensitive plates, and small ring magnets. The robot has eyes, ears and arms - Photocells, microphones, steel claws. It takes orders - by those who know how to give them. It answers - in the form of mathematical solutions or actions. (Expressen 14.08.1955)

In this fashion the new machines - inanimate objects such as electronic wires and steel - were rewarded with properties otherwise restricted to the living labour. "This is what a machine can do in the year 1956. Receive an order. Execute it. Assess the outcome. Detect a problem. Fix it.", Expressen announced (Expressen 22.06.1955). Besides replacing human bodily functions and properties, the machines - robots - were now seen as more or less living agents, able to perform actions such as "learning", "feeling", "knowing", "remembering", "taking orders", "obeying" and "executing" etc... Feedback was seen as "the robot's surrogate for a soul" (Expressen 23.02.1955). Some went so far as to argue that the new machines were able to express "love" (Expressen 22.06.1955). The future was about to be populated by robots, whose core purpose in life was to produce social progress and economic development. "Future humanity takes its side - lets ROBOTS CREATE PROSPERITY!” Aftonbladet dramatically announced (Aftonbladet 09.07.1957).

\section{From fetish to forced adaptation}

At a more abstract, or structural level, technological development as such was treated as a powerful force, demanding adherence. This, for instance, was implied by three different, but all future-oriented and highly influential conferences organised by actors within the employer's side of industry as well as by the labour movement, during the mid-1950s. Backed by the Swedish Employers Agency, in 1954, the Swedish think-tank SNS organised a conference, gathering corporate leaders and researchers committed to discussing the implications of automation for the future economic development of society (Ny teknik - nya perspektiv 1954). In continuation, the governing Social Democratic Workers Party the following year (1955) organised a similar conference together with the Swedish Trade Union Confederation. The conference, Technology and the society of tomorrow", gathered both scientists, union representatives and politicians as well as corporate representatives, to discuss how society was to adapt and accommodate to the new technological and scientific advancements (Tekniken och morgondagens samhälle 
1956). In 1956 a third conference by the name: Man in today's and tomorrow's society was organised by the Workers' Educational Association. Leading scientists, politicians, employers and unions were again invited to discuss the future, but this time with the aim of addressing the perceived omissions of previous conferences to discuss the implied human adaptation to changes in working life and society How were people to be "psychologically prepared" to accept the pending changes? (Människan i dagens och morgondagens samhälle 1956).

Together the three conferences signified a holy trinity in the Swedish model for socio-economic progress: profit growth, social policy, and disciplining the labour force, all under the umbrella of an unavoidable technological development. The outline of such a thought was sketched out in the following quote, published in Stockholms-Tidningen:

The importance of the fact that our small country from the first moment is part of the technical development hardly needs to be emphasized. Thanks to outstanding technicians and a reputable workforce, we have so far been able to stand strong in the face of competition, keep our productivity and hence also our prosperity. As it is now, in the near future, possible to talk about profound transformations of our industry, perhaps also extensive retraining of labour, it is of particular importance that business freedom and development opportunities are not cut. (Stockholms-Tidningen 14.06.1956)

The job of politicians was primarily to facilitate the conditions for the technological development to run as smooth and efficiently as possible. Part of this involved removing any possible obstacle ahead. In his speech during the 1955 conference Technology and tomorrow's society the political economist Ingvar Svennilson commented upon the "human factor". He argued that: "The biggest obstacle to society's economic development is lack of technical knowledge among the people in general and especially the lack of qualified technicians and business leaders" (Tekniken och morgondagens samhälle 1956: 259). ${ }^{4}$ Robots demanded expert care and specialist service, and political economists like Svennilson pointed to how Sweden suffered from a lack of technicians. While the new machines were seen as inevitably leading society into a new era, there was a problem: the world was inhabited by a species of less advanced creatures holding them back. The biggest complicating circumstance for society to reach its full potential was the habitual inertia of human consciousness. The technological and scientific development thus demanded a new and improved professional training, both among existing and future labour forces (Ginner 1988: 103f).

As a technically savvy labour force was considered a significant production 
factor, and the lack of educated labourers risked becoming an obstacle for progress, people would have to be strategically moulded according to the needs of technology in order to reach the promised land of industrially produced surplus and growth (Ginner 1988: 107). Technological development therefore demanded a reconfiguration of the Swedish education system for supplying Sweden with new generations of scientists, engineers and technicians (Wennerholm 2005: 159; 287; Pettersson 2012: 148). In the future automated working life, a new form of labouring subject was needed, demanding a change of mentality among the individuals within the work force. Not only was the work force expected to satisfactorily perform the duties demanded by the new technology. They would also have to internalise the desire to "adapt, develop and improve at work" as well as a "perspective of cost awareness" corresponding to the goals of the organisation (Landsorganisationen i Sverige 1966: 22).

In this way humanity - or at least the general population - was in the face of technological development, treated as passive bystanders, expected to prepare and adapt, socially, economically and psychologically to the needs of the machines (Tekniken och morgondagens samhälle 1956: 301). In order to realise the promises of tomorrow, the labour force should be in a state of continuous adaptation to the changes produced by robots. Agency and power in the production of society was transposed from humans to their machines, from the labour force, to the means of production (cf. Marx 2013: 367f).

\section{The juggernaut of modernist ideology and the utopia of human agency}

[E]mancipatory politics must always destroy the appearance of a 'natural order', must reveal what is presented as necessary and inevitable to be a mere contingency, just as it must make what was previously deemed to be impossible seem attainable. (Fisher 2009: 16f)

In order to interpret the meaning of the Robot Revolution as it appeared in the press we should briefly recall the hopeful image of the benevolent robot liberating humanity from poverty and tedious tasks, and the dystopic image of a future in which the wellbeing of humans was dictated by machines, around which the Robot Revolution was constructed. Together both visions served as opposing parts around which the discourse on the automated future constituted itself. Although contradictory, however, both visions drew from an immanent juxtaposition of humans and robots. ${ }^{5}$ The robot - a powerful agent - was contrasted to the insignificant humans, helplessly marvelled at the workings of the machine. The Robot Revolution thus seemed to confine humanity to the peripheral role of an observer. 
Relegated to a decentred position outside the unfolding of events, humanity appeared as the object, rather than the subject of change.

According to the German theorist Walter Benjamin, the systematic organisation around abstract goals such as the "universal betterment of mankind" will under capitalism first of all serve the interests of capital (Benjamin 1969: 260). Together with his colleagues in the Frankfurt school, he argued that if decisions regarding the social trajectory was determined by universal goals, "progress" would inevitably come across as alien and de-humanising to those affected by it (cf. Marcuse 1991; Habermas 1980). Others have similarly attempted to describe modern capitalism as an indifferently abstract force by using the metaphor of a machine, carrying humanity towards an unknown destiny (Rosa 2013; Beck 1992; Giddens 1990).

The Robot Revolution here appeared as a reified form of anticipatory knowledge. As such, it was also a document of a certain point in social history. In relation to the contemporary debate, one could say that the Robot highlighted a perceived separation between humanity and their means of production. It accentuated the gap between technology's actual potential to liberate people from suffering, and the experience of nonparticipation and democratic deficit of a social model stressing compulsory innovation and investments in new machines for the sake of perpetual growth (cf. Morris-Suzuki 1984). Altogether the Robot Revolution thus stressed a central paradox of Swedish welfare capitalism. It confronted the audience with a social formation under which the needs of concrete human beings were subordinated the abstract laws of competition, and a political consensus regarding such a system as a method to achieve liberation at a universal scale. The experience of a social formation in which technological development itself assumed the role as the subject of history was symbolically processed and resolved through the appearance of a powerful machine, functioning independently of human intervention or control.

As a unity of opposites, the Robot Revolution served as a totality through which conflicting social experiences could be contained. As such it functioned ideologically as a reaffirmation of some basic assumptions regarding the nature of social change. Both anticipations of the pending robot revolution unified under the assumption that technological development was a self-governing force inevitably revolutionising society.

Yet, as argued by Jameson, the critical analysis of cultural artefacts should not settle with demystifying how they serve to reaffirm existing convictions regarding the future. The true job of the radical analyst is rather to open up new avenues of expectation and rediscover the utopian potential that they secretly embody. Approached dialectically, the Robot Revolution was not just a passive reflection of dominant ideology. It also secretly suggested a utopian dimension that latent- 
ly negated the prevailing configuration of social reality (cf. Jameson 2002[1981]: $276 \mathrm{ff})$. As an object of ideology, it prefigured the shapes of an alternative society through which its immanent contradictions could be transcended and resolved (cf. Eagleton 1991: 1f, 106). By looking at notions that transcended and contradicted what was explicitly articulated, one could redeem this disavowed utopia and find the vague outlines of an incongruous "not yet" through which the possibilities of an "otherwise" - where humanity could reclaim the democratic control over technological development and ultimately one's own future, as a subject of history - could be reimagined.

Daniel Bodén $(\mathrm{PhD})$ is currently a lecturer at the Department of History and Contemporary Studies at Södertörn University. His research primarily covers the intersection between technology and culture, and draws from an interest in historical change as well as labour and contemporary modes of everyday life. E-mail: daniel.boden@sh.se

\section{Notes}

${ }^{1}$ In this article, all translations from Swedish to English are the author's. In cases where a word, statement or concept is hard to translate literally, the original Swedish formulation will be stated in the endnotes.

${ }^{2}$ "The people's home" was an important political concept in the history of the Swedish welfare state that signified the abandonment of class struggle to the benefit of consensus politics.

${ }^{3}$ This position stood in contrast to large parts of the international labour movement, which was more combative and gravitated towards a view of machinery as weapons, wielded by capital in an ongoing struggle against the working class. In April and May 1956, for example, 11,000 workers at Standard Motor Company in the English city of Coventry, went on strike, unwilling to accept the layoff of 3000 workers, as had been decided by the company following the implementation of a new partially automated production process (Castoriadis 1988:26ff).

4"Låt mig börja med den mänskliga faktorn: Det största hindret för samhällets ekonomiska utveckling är brist på tekniska kunskaper bland folket i allmänhet och speciellt brist på kvalificerade tekniker och företagsledare".

${ }^{5}$ I have elsewhere argued that the juxtaposition of humans to robots gathers its tension from their mutual existence as competing commodities in the capitalist labour market, and that the inherent contradiction draws from conflicting social interests between labour and capital (Bodén 2017). 


\section{Culture Unbound}

Journal of Current Cultural Research

\section{References}

Aftonbladet, 17.11.1955; 09.07.1957; (National Library of Sweden).

Automationen: fakta och följder. (1956). Stockholm: Industriens upplysningstjänst. (National Library of Sweden).

Barthes, Roland (1981): Camera Lucida: Reflections on Photography. New York: Hill and Wang

Beck, Ulrich (1992): Risk Society: Towards a New Modernity. London: Sage

Beckman, Svante (red.) (1990): Teknokrati, arbete, makt. Stockholm: Carlsson

Benjamin, Walter (1969): Illuminations. New York: Schocken Books

Berger, John (2007): Berger on Drawing. $2^{\text {nd }}$ ed. Aghabullogue: Occasional Press

Berman, Marshall (1988[1982]): All That is Solid Melts Into Air: the Experience of Modernity. New York, N.Y., U.S.A.: Viking Penguin

Bloch, Ernst (1995): The principle of hope. Vol.1. Cambridge, Mass.: MIT Press

Bodén, Daniel (2017): "'Robotrevolutionen', verkligheten och fiktionen", Kulturella perspektiv - Svensk etnologisk tidskrift, $\mathrm{nr} 2$

Carlsson, Anders, (1999): "Tekniken - politikens frälsare? Om matematikmaskiner, automation och ingenjörer vid mitten av 50-talet", Arbetarhistoria. 1999, nr 92, pp. 23-30.

Castoriadis, Cornelius (1988): Political Writings, vol 2 1955-1960: From Workers Struggle against Bureaucracy to Revolution in the Age of Modern Capitalism. Minneapolis: University of Minnesota Press.

Dagens Nyheter, 09.07.195 (National Library of Sweden).

De Geer, Hans (1992a): På väg till datasamhället: datatekniken i politiken 19461963. Stockholm: Tekniska högsk.

De Geer, Hans (1992b): Arbetsgivarna: SAF i tio decennier. Stockholm: Svenska arbetsgivarefören. (SAF)

Eagleton, Terry (1991): Ideology: an Introduction. London: Verso

Expressen, 14.08.1955; 21.02.1955; 23.02.1955; 22.06.1955; 23.08.1955; 22.02.1956 (National Library of Sweden).

Fisher, Mark (2009): Capitalist Realism. Is There No Alternative? Winchester: O-books

Giddens, Anthony (1990): The Consequences of Modernity. Cambridge: Polity in association with Blackwell

Ginner, Thomas (1988): Den bildade arbetaren: debatten om teknik, samhälle och bildning inom Arbetarnas bildningsförbund 1945-1970. Diss. Linköping : Univ.

Habermas, Jürgen (1980): Toward a rational society. Student Protest, Science, and Politics. London: Heinemann Educational Books

Isacson, Maths (2012): "Arbetets skiftande villkor", Magnusson, Lars \& Ottosson, Jan (eds.). Den hållbara svenska modellen. Innovationskraft, förnyelse och effektivitet. 1. uppl. Stockholm: SNS förlag

Jameson, Fredric, (2002): The Political Unconscious: Narrative as a Socially Symbolic Act, London: Routledge

Kandinsky, Wassily, (1946): On the Spiritual in Art. Solomon R. Guggenheim Museum

Landsorganisationen i Sverige (1966). Fackföreningsrörelsen och den tekniska utvecklingen. Rapport från en arbetsgrupp till 1966 års LO-kongress, Stockholm: Bokförlaget Prisma (Arbetarrörelsens arkiv och bibliotek).

Ljungberg, Gregory (1956): Automationen: fakta och följder. Stockholm: Industriens upplysningstjänst

Marcuse, Herbert (1991[1964]): One-Dimensional Man: Studies in the Ideology of Advanced Industrial Society. Boston: Beacon Press

Marx, Karl (1977 [1867]): Capital, Volume one. New York: Vintage

Marx, Karl \& Engels, Friedrich (1990[1983]): Manifesto of the Communist Party. 
London: Lawrence \& Wishart

Morris-Suzuki, Tessa (1997): "Robots and Capitalism”, Davis, Hirschl, Stack, (ed.). Cutting Edge: Technology, Information, Capitalism and Social Revolution. London: Verso

Människan i dagens och morgondagens samhälle. Del 1, (1956a). Stockholm: Arbetarnas bildningsförbund (National Library of Sweden).

Människan i dagens och morgondagens samhälle. Del 2, (1956b). Stockholm: Arbetarnas bildningsförbund (National Library of Sweden).

Ny teknik - nya perspektiv: Näringslivet planerar för framtden. Referat från SNS företagsledarkonferens i Tylösand 17-20 maj 1954. (1954). Stockholm: SNS (National Library of Sweden).

Pettersson, Ingemar (2012): Handslaget: svensk industriell forskningspolitik 19401980. Diss. Stockholm: Kungliga Tekniska högskolan, 2012.

Rosa, Hartmut (2013): Social Acceleration: A New Theory of Modernity. New York: Columbia University Press

Stockholms-Tidningen, 05.05.1956; 14.06.1956 (National Library of Sweden).

Svenska Dagbladet, 20.09.1951; 19.09.1951 (National Library of Sweden).

Tekniken och morgondagens samhälle. (1956). Stockholm: Tiden (National Library of Sweden).

Wennerholm, Staffan (2005): Framtidsskaparna: vetenskapens ungdomskultur vid svenska läroverk 1930-1970. Diss. Uppsala : Uppsala universitet, 2005 